Dostępne online www.journals.wco.pl/los

Zeszyty Naukowe WCO, Letters in Oncology Science 2021;18(3):76-80

CrossMark
Artykuł oryginalny / Article
ISSN 2543-6724

ZESZYTY NAUKOWE WIELKOPOLSKIEGO CENTRUM ONKOLOGII

\title{
Użyteczność badania 18F-FDG PET/CT w diagnostyce raka krtani.
}

\section{The utility of the $18 F-F D G$ PET/CT study in the laryngeal cancer diagnosis.}

\author{
Aleksandra Feldgebel ${ }^{1}$, Adrianna Medak ${ }^{1}$, \\ Witold Cholewiński ${ }^{1}$, Agata Pietrzak ${ }^{1}$
}

${ }^{1}$ Katedra i Zakład Elektroradiologii, Uniwersytet Medyczny im. K. Marcinkowskiego w Poznaniu

\section{Streszczenie}

Rak krtani jest jednym z najczęściej wykrywanych nowotworów złośliwych regionu głowy i szyi. Z uwagi na wysoki stopień złośliwości oraz wczesne przerzuty odległe, rak krtani wymaga wczesnej i złożonej diagnostyki. Metodą z wyboru w ocenie guzów regionu głowy i szyi jest badanie pozytonowej tomografii emisyjnej/tomografii komputerowej z użyciem 18F-fluorodeoksyglukozy (18F-FDG PET/CT).

\footnotetext{
Abstract

Adres do korespondencji

Aleksandra Feldgebel

Katedra i Zakład Elektroradiologii,

Uniwersytet Medyczny im. K. Marcinkowskiego w Poznaniu, Polska

Telefon. +48618850789

e-mail: ola.feldgebel@gmail.com
}

Laryngeal cancer is one of the most common head and neck malignant neoplasm, demanding early and detailed diagnosis. The method of choice in the head and neck tumors imaging is the 18F-fluorodeoxyglucose positron emission tomography/computed tomography (18F-FDG PET/CT) study.

Słowa kluczowe: 18F-Fluorodeoksyglukoza, pozytonowa tomografia emisyjna, rak krtani

Keywords: fluorine-18F-fluorodeoxyglucose, positron emission tomography, laryngeal cancer 


\section{Wstęp}

Rak krtani jest jednym z najczęstszych nowotworów złośliwych regionu głowy i szyi. Dominującym typem histologicznym raka krtani jest typ płaskonabłonkowy. Rak krtani występuje najczęściej wśród mężczyzn po 50. roku życia, a czynniki ryzyka zachorowania obejmują m.in. palenie tytoniu oraz nadmierne spożywanie alkoholu [1,2]. Zdaniem badaczy [1], jednoczesne i długotrwałe oddziaływanie tych czynników zwiększa ryzyko wystąpienia tego nowotworu nawet 330-krotnie (tzw. zjawisko multiplikacji). Wśród objawów rozwijającego się raka krtani wyróżniamy m.in.: chrypkę lub bezgłos, duszności, a z czasem - niedokrwistość [3]. W zależności od stopnia zaawansowania choroby, terapia obejmuje przezustną mikrochirurgię laserową, częściową lub całkowitą laryngektomię, a także leczenie chirurgiczne skojarzone z radiochemioterapią [4].

Złotym standardem w diagnostyce chorób onkologicznych jest ocena histologiczna. Metodą z wyboru $\mathrm{w}$ diagnostyce obrazowej raka krtani jest pozytonowa tomografia emisyjna/tomografia komputerowa $\mathrm{z}$ użyciem ${ }^{18} \mathrm{~F}$-fluorodeoksyglukozy (z ang. ${ }^{18} \mathrm{~F}$-fluorodeoxyglucose positron emission tomography/computed tomography, ${ }^{18} \mathrm{~F}-\mathrm{FDG}$ PET/CT). Za użyteczne metody oceny raka krtani uznawane są także: tomografia komputerowa ze wzmocnieniem kontrastowym ( $\mathrm{z}$ ang. contrast-enhanced computed tomography, ceCT) i rezonans magnetyczny ( $\mathrm{z}$ ang. magnetic resonance imaging, MRI) [5,6].

\section{Cel pracy}

Celem niniejszej pracy jest wykazanie użyteczności badania ${ }^{18} \mathrm{~F}-\mathrm{FDG}$ PET/CT w diagnostyce raka krtani w oparciu o dostępne piśmiennictwo oraz dane oryginalne.

\section{Material i metoda-}

Analizie poddano dziesięcioro chorych onkologicznie z podejrzeniem lub rozpoznaniem nowotworu złośliwego krtani (mężczyźni w wieku 38 - 77 r.ż., średnia wieku \pm odchylenie standardowe; OS; $57 \pm 13$ lat), poddanych badaniu ${ }^{18} \mathrm{~F}$-FDG PET/CT. Akwizycję wykonano w pozycji leżącej na plecach po wcześniejszym nawodnieniu oraz pomiarze glikemii na czczo. Skanowanie zostało rozpoczęte po 60 minutach (min) po dożylnej iniekcji radioznacznika ${ }^{18} \mathrm{~F}-\mathrm{FDG}$ o aktywności 3,7 megabecquereli/kilogram masy ciała (MBq/ $\mathrm{kg}$ ). Parametry akwizycji CT obejmowały natężenie 150-200 miliamperosekund (mAs), napięcie lampy rentgenowskiej 120 kilowoltów (kVp), skok o,81. Pojedyncze sektory PET skanowano, stosując okno czasowe 90 sekund (s). Akwizycja danych obejmowała obszar: szczyt czaszki - połowa długości kości udowych.

Badania wykonano skanerem hybrydowym PET/CT Philips Gemini TF16 (Philips, Cleveland, Ohio, Stany Zjednoczone). Analiza danych oryginalnych obejmowała ocenę ogniska pierwotnego (OP) i przerzutów odległych, a także określenie stopnia utylizacji radiofarmaceutyku w ww. ogniskach. Aktywność metabolizmu glukozy mierzona była z użyciem dedykowanego metodzie PET parametru maksymalnej standaryzowanej wartości wychwytu (z ang. maximal Standardized Uptake Value, SUVmax).

\section{Wyniki}

Obrazowanie za pomocą metody PET/CT jest możliwie dzięki wykorzystaniu radioizotopów, które są emiterami pozytonów. Detekcja kwantów gamma pochodzących z jednej anihilacji, rejestrowana jest w trakcie tzw. koincydencji, czyli czasowo-przestrzennej zbieżności wykrycia dwóch kwantów o energii charakterystycznej $511 \mathrm{keV}$ lub zbliżonej. Połączenie skanera PET z aparatem CT umożliwia precyzyjne określenie rozkładu radioznacznika w ciele osoby badanej.

Najczęściej wykorzystywanym w praktyce klinicznej radiofarmaceutykiem jest ${ }^{18} \mathrm{~F}-\mathrm{FDG}$ [7]. Technika ${ }^{18}$ F-FDG PET/CT znalazła szerokie zastosowanie w diagnostyce wielu schorzeń onkologicznych [8,9]. Jest to metoda $\mathrm{z}$ wyboru w ocenie zmian w regionie głowy i szyi, stosowana celem wykrycia OP, oceny stopnia zaawansowania choroby, a także planowania i oceny skuteczności zastosowanego leczenia. Z uwagi na nieswoisty charakter radioznacznika ${ }^{18} \mathrm{~F}-\mathrm{FDG}$, diagnostyka różnicowa zmian łagodnych i złośliwych w regionie głowy i szyi może być utrudniona.

W niniejszej pracy dokonano analizy retrospektywnej grupy badań 10. chorych z rozpoznanym rakiem krtani, którzy zostali poddani skanowaniu ${ }^{18}$ F-FDG PET/CT. Wskazania do badania obejmowały: wykrycie 
guza pierwotnego (podejrzenie nowotworu złośliwego regionu głowy i szyi z uwagi na obecność przerzutów do węzłów chłonnych szyi), ewaluacja stopnia zaawansowania choroby przed rozpoczęciem leczenia oraz określenie skuteczności zastosowanej terapii (ocena wznowy nowotworowej).

Tabela 1. przedstawia wartości wskaźnika SUVmax w obszarze wykrytych badaniem guzów krtani: Zanonimizowane dane oryginalne (źródło: ZMN WCO)

\begin{tabular}{ccc} 
LP & Cel badania PET/CT & SUVmax \\
\hline 1 & CUP & 5,62 \\
\hline 2 & CUP & 4,11 \\
\hline 4 & CUP & 3,32 \\
\hline 5 & CUP & 3,62 \\
\hline 6 & Ocena zaawansowania & 5,29 \\
\hline 7 & Ocena zaawansowania & 5,20 \\
\hline 8 & Ocena zaawansowania & 7,04 \\
\hline 9 & Ocena zaawansowania & 4,03 \\
\hline 10 & Ocena wznowy & 3,29 \\
\hline
\end{tabular}

Zdaniem autorów [10,11], wartości SUVmax przekraczające 2,5 mogą wskazywać na złośliwy charakter ogniska, niezależnie od badanego regionu [12]. Wśród wybranej grupy chorych, wartość SUVmax wahała się w przedziale $3-7$, co może wskazywać na proces złośliwy.

W każdym z badanych przypadków, wartość SUVmax przekraczała 2,5, co sugerowało proces złośliwy. Chorzy poddani zostali weryfikacji histologicznej oraz dodatkowym badaniom (w tym: kontrola z użyciem ${ }^{18}$ F-FDG PET/CT). We wszystkich przypadkach, rozpoznano rak płaskonabłonkowy krtani.

Istotnym parametrem oceny chorych z rozpoznanym i kwalifikowanym do leczenia nowotworem była ocena obecności przerzutów odległych w tkankach miękkich i kościach (ocena stopnia zaawansowania, staging).-

Ewaluacja skuteczności leczenia (ocena wznowy, restaging) wykazała nawrót choroby, który został potwierdzony histologicznie po wykonaniu badania ${ }^{18} \mathrm{~F}-\mathrm{FDG}$ PET/CT. W wybranej grupie chorych, czułość i swoistość metody w ocenie raka krtani sięgała 100\%.

\section{Dyskusja}

Nowotwory głowy i szyi zajmują szóste miejsce wśród najczęściej występujących nowotworów złośliwych. Dominującym typem histologicznym jest rak płaskonabłonkowy, ulokowany zazwyczaj w rejonie dna jamy ustnej, gardła i krtani [7]. Wczesne objawy choroby nie są specyficzne i często mogą być mylone z przewlekłym zapaleniem krtani [14]. Panendoskopia z pobraniem bioptatu jest złotym standardem w diagnostyce raka krtani, jednak ograniczeniem metody jest niska dostępność guza położonego w dolnym piętrze krtani. Metodą $\mathrm{z}$ wyboru w ocenie guzów regionu głowy i szyi jest badanie ${ }^{18} \mathrm{~F}-\mathrm{FDG}$ PET/CT, a do technik uzupełniających diagnostykę należą: ceCT, MRI oraz USG. Wykorzystanie wielu badań diagnostycznych umożliwia precyzyjną 
ewaluację guza, która pozwala wdrożyć odpowiednią terapię [6]. Zastosowanie techniki ${ }^{18} \mathrm{~F}-\mathrm{FDG}$ PET/CT pozwala na ocenę stopnia zaawansowania choroby dzięki skanowaniu całego ciała w trakcie jednej akwizycji (ocena ogniska pierwotnego, zaawansowania węzłowego, ognisk wtórnych w układzie kostnym).

W niniejszej pracy dokonano analizy danych oryginalnych dotyczących 10. chorych z rozpoznanym rakiem krtani, poddanych badaniu ${ }^{18}$ F-FDG PET/CT. Ocena skanów akwizycyjnych, obejmująca pomiar wskaźnika SUVmax, pozwoliła na potwierdzenie obecności procesu złośliwego. W każdym z badanych przypadków, parametr SUVmax przekroczył rekomendowany próg aktywności metabolizmu glukozy, który wynosi 2,5. Według autorów [10,11], wartość SUVmax przekraczająca 2,5, sugeruje złośliwy charakter badanej zmiany. Przeprowadzenie badania PET/CT z użyciem radiofarmaceutyku ${ }^{18} \mathrm{~F}$-fluorodeoksyglukozy umożliwiło wskazanie obecności przewidywanego ogniska pierwotnego i przerzutów do węzłów chłonnych szyi, a także wznowy nowotworowej.

\section{Wnioski}

Metoda ${ }^{18} \mathrm{~F}-\mathrm{FDG}$ PET/CT jest badaniem użytecznym w wykrywaniu ogniska pierwotnego, ocenie zaawansowania oraz ewaluacji skuteczności leczenia raka krtani.

\section{Konflikt interesu / Conflict of interest}

Nie występuje / None

\section{Etyka / Ethics}

Treści przedstawione w artykule są zgodne z zasadami Deklaracji Helsińskiej, dyrektywami EU oraz ujednoliconymi wymaganiami dla czasopism biomedycznych.

\section{Bibliografia}

[1] Majszyk, D., Bruzgielewicz, A., \& Osuch-Wójcikiewicz, E. Rak krtani - epidemiologia i etiologia. Polski Przegląd Otorynolaryngologiczny. 2014; 3(4), 186-188.

[2] Kaczmarczyk, D., Bruzgielewicz, A., Osuch-Wójcikiewicz, E. Histopatologia i zmiany przedrakowe w raku krtani. 2014

[3] Tresley, J., Saraf-Lavi, E., Kryvenko, O., Sargi, Z. Epiglottic masses identified on CT imaging: A case report and review of the broad differential diagnosis. The Neuroradiology Journal. 2015; 28(3), 347353.

[4] Jones, T. M., De, M., Foran, B., Harrington, K., Mortimore, S. Laryngeal cancer: United Kingdom National Multidisciplinary guidelines. The Journal of Laryngology \& Otology. 2016; 130(S2), S75-S82.

[5] Sun, C., Han, X., Li, X., Zhang, Y., Du, X. Diagnostic Performance of Narrow Band Imaging for Laryngeal Cancer: A Systematic Review and Meta-analysis. Otolaryngology-Head and Neck Surgery. 2017; 156(4), 589-597.

[6] Agnello, F., Cupido, F., Sparacia, G. i wsp. Computerised tomography and magnetic resonance imaging of laryngeal squamous cell carcinoma: A practical approach. The Neuroradiology Journal. 2017; 30(3), 197-204.

[7] Siddiqui, F., Yao, M. Application of fluorodeoxyglucose positron emission tomography in the management of head and neck cancers, 2014.

[8] Medak, A., Wojtowicz, J., Pietrasz, K. i wsp. The utility of the 18F-FDG PET/CT in the primary and metastatic brain lesions diagnosis. Letters in Oncology Science 2020;17(3):114-118.

[9] Abouzied, M., Fathala, A., Alsugair, A. i wsp. Role of Fluorodeoxyglucose-Positron Emission Tomography/ Computed Tomography in the Evaluation of Head and Neck Carcinoma. 2017; World J Nucl Med. OctDec; 16(4): 257-265.

[10] Zhang, L., Wang, Y., Lei, J., Tian, J., Zhai, Y. Dual time point 18FDG-PET/CT versus single time point 18FDG-PET/CT for the differential diagnosis of pulmonary nodules: a meta-analysis. Acta Radiologica. 2013; 54(7), 770-777. 
[11] Kadaria, D., Freire, A. X., SultanAli, I. i wsp. Dual Time Point Positron Emission Tomography/Computed Tomography Scan in Evaluation of Intrathoracic Lesions in an Area Endemic for Histoplasmosis and With High Prevalence of Sarcoidosis. The American Journal of the Medical Sciences. 2013; 346(5), 358362.

[12] Anderson, C., Chang, T., Graham, M. i wsp. Change of Maximum Standardized Uptake Value Slope in Dynamic Triphasic [18F]-Fluorodeoxyglucose Positron Emission Tomography/Computed Tomography Distinguishes Malignancy From Postradiation Inflammation in Head-and-Neck Squamous Cell Carcinoma: A Prospective Trial. International Journal of Radiation Oncology*Biology*Physics. 2015; 91(3), 472-479.

[13] Ahn SH., Hong HJ., Kwon SY. i wsp. Guidelines for the Surgical Management of Laryngeal Cancer: Korean Society of Thyroid-Head and Neck Surgery. 2017; Clin Exp Otorhinolaryngol; 10:1-43.

[14] Shephard, E. A., Parkinson, M. A., Hamilton, W. T. Recognising laryngeal cancer in primary care: a large case-control study using electronic records. British Journal of General Practice. 2019. 